\title{
System Dynamics Modeling Strategy for Civil Construction Projects: The Concept of Successive Legislation Periods
}

\author{
Wang Jing ${ }^{1,2}$, Hafeth Ibrahem Naji ${ }^{3}$, Raquim Nihad Zehawi ${ }^{3}$, Zainab Hasan Ali ${ }^{3}$, \\ Nadhir Al-Ansari 4 (D) and Zaher Mundher Yaseen ${ }^{5, *(D)}$ \\ 1 Department of Computer science, Baoji University of Arts and Sciences, Baoji 721000, China; \\ jingwang0720@gmail.com \\ 2 Faculty of Computer Systems \& Software Engineering, University Malaysia Pahang, Pahang 26600, Malaysia \\ 3 Department of civil Engineering, College of Engineering, University of Diyala, Baquba 32001, Iraq; \\ hafizibrahem1973@gmail.com (H.I.N.); raquim_zehawi@yahoo.com (R.N.Z.); \\ zainabhasan222@gmail.com (Z.H.A.) \\ 4 Civil, Environmental and Natural Resources Engineering, Lulea University of Technology, \\ 97187 Lulea, Sweden; nadhir.alansari@ltu.se \\ 5 Faculty of Civil Engineering, Ton Duc Thang University, Ho Chi Minh City, Vietnam \\ * Correspondence: yaseen@tdtu.edu.vn; Tel.: +84-0334987030
}

Received: 18 April 2019; Accepted: 14 May 2019; Published: 16 May 2019 updates

\begin{abstract}
Cost and time performance are considered to be the most important aspects in the construction industry. The exceptional conditions that took place in Iraq since the beginning of the third millennia had a huge vicious impact on the cost and time performance of local construction projects. This may represent the principal motivation for the local authorities to enact some four successive legislations in order to control the performance of the construction industry. In this research, an evaluation is made to the cost and time performance of local construction projects and their variation due to the multiple changes in the internal factors that affect project performance, and changes in the surrounding events include legislative, economic, and security environment during the period that lasted from 2003 to 2014. Data is collected from 30 governmental projects to conduct the evaluation. A comprehensive questionnaire is performed to estimate a quantitative value for the impact of several factors that concern both the owner and the contractor, with special consideration to their variation through the successive legislation periods. These estimates are, in turn, utilized in a system dynamics model, in which the project development process is simulated. The final cost and duration changes in the project are accumulated in the form of stocks to give an indication of the cost and time performance of the project. The developed model returned a progressive reduction of $10.9 \%$ for the change in project cost and $135.37 \%$ for the change in project schedule throughout the eleven years period.
\end{abstract}

Keywords: change management; construction sector; legislation; system dynamics; cost performance; time performance

\section{Introduction}

\subsection{Background}

The construction sector has a strategic role in improving economics in developed countries [1]. However, this sector often suffers from major problems, such as delays, cost overrun, and quality defects [2]. The main causes of these problems are the changes in construction project [3,4]. Changes 
can be caused by multiple factors and they could be categorized into internal and external factors. Internal factors are classified into owner related, design related, and contractor related factors. Whereas, the external factors include changes in issues that related to economic, environment, technology, politic, legislation, and force majeure [5-7]. The risky circumstances that are caused by terrorism, war, and instability of politic environment in Iraq give the performance of construction projects special importance in Iraq after 2003 [8]. Legislations have been changed to reduce the impact of these risky circumstances on the construction industry [9]. Change in legislation is included in the modification to many terms that are related to the selection and classification of contractor.

\subsection{Literature Review}

Construction change is defined as an adjustment to the construction process, including the program of project, design aspect, or alteration to other existing requirements of project, conditions, or assumptions [4]. Changes can happen due to many events that contribute to changes in a construction project [10]. Numerous studies have been carried out on causes of delays and changes in construction project. The causes of changes can be categorized into external and internal factors. External factors include unexpected site condition, regulation changes, changes in the authority of decision making, and unanticipated weather condition [6]. Internal causes of changes can be classified into causes related to owner, design and contractor [6,7]. By recalling the literature, Iyagba and Ijaola [11] indicated in their study that the "clients' additional works and modification to design" were the most important reasons of change order in both Nigeria and Oman. According to Elawi et al. [12], the factors of delay that contributed to the majority of time overrun were the acquisition of land, expertise lack of contractor, re-designing, and line services (haphazard underground utilities). Performance issues is rather pronounced in the local construction industry due to the special circumstances and tragic working environment in the wake of the last war in 2003 and its consequences in the following years. Many governmental projects stumbled and failed to complete due to many reasons, such as politic environment, economic, and security situation [13].

In order to reduce the impact of these risky events on the construction industry, legislations have been changed many times during the period from 2003 to 2014 [9]. The changes included many acts, such as the General Term of the Civil Engineering Contracts, Governmental contracts implementation Instructions no.1, and the Registry Instructions of Iraqi Contractor (RIC).

Additionally, the ministry of planning made changes in their regulations that concern the certification of materials source and the regulation for blacklisting contractor who failed to fulfill their previous obligations $[9,14]$. These legislations make a suitable enhancement on the time performance of construction project during the period from 2003 to 2014 [9]. The effects of the legislative changes on the construction performance could best be observed and quantified through the dynamic modeling, which is commonly used in construction projects [15]. Project construction is dynamic in nature and involves many feedback loops that are caused by the rework process [16-18]. These features cannot be easily explicated using the traditional method or simple statistical analysis [19]. The system dynamics approach, which was originated by Jay Forrester (1960), has been widely utilized in modeling construction projects management to describe the complexity of feedback process in project management $[20,21]$. In this approach, the system is modeled by a combination of independent variables that interact with each other in a stable way, where two major characteristics are presented [22,23]. The first is the change of variables over time and the second is the feedback effect [24]. The system is used to model and enhance the management of the dynamic system by focusing on describing the component of system in a realistic way [20].

Over the past two decades, several researchers applied system dynamics model in construction project management. For instance, Ogunlana et al. [25] investigated the strategies of enhancing the performance of construction project by using the system dynamics model. In another study, Nasirzadeh and Nojedehi [26] used a system dynamics strategy to model the labor productivity in a construction project. 
Important researches in system dynamics that deal with issues that are related to changes and errors in projects, asserting the rework cycle impact on project performance $[16,19,27]$. Love et al. [3] used a case study and system dynamics methodology to describe the impact of changes and rework on the project management system. The authors observed the major factors that influenced the performance of a project. They found that there is a need to understand how particular dynamics could delay the performance of a project management system. Lee et al. [28] proposed a framework to determine the impact of iterative cycle on the performance of concurrent design and construction projects, and this framework was then integrated with system dynamics model to evaluate the negative impacts of changes and errors on construction performance. In 2007, Lee and Peña-Mora [29] concluded that the integration of system dynamics model with other tools can assist the managers in controlling the error and change in construction project. Motawa et al. [30] used the system dynamics model to simulate the rework cycle in construction project and evaluate the impact of their changes. Han et al. [31] studied the dynamic of design defects and their impact on the performance of the construction project. For this purpose, the authors developed a system dynamics model and concluded that the model can help to understand the dynamics of design defects and then enhance the progress of a construction project. For better visualization, a summary of previous studies outcomes is listed to justify the current study contribution (See Table 1).

Table 1. Comparison between the current study and previous conducted studies.

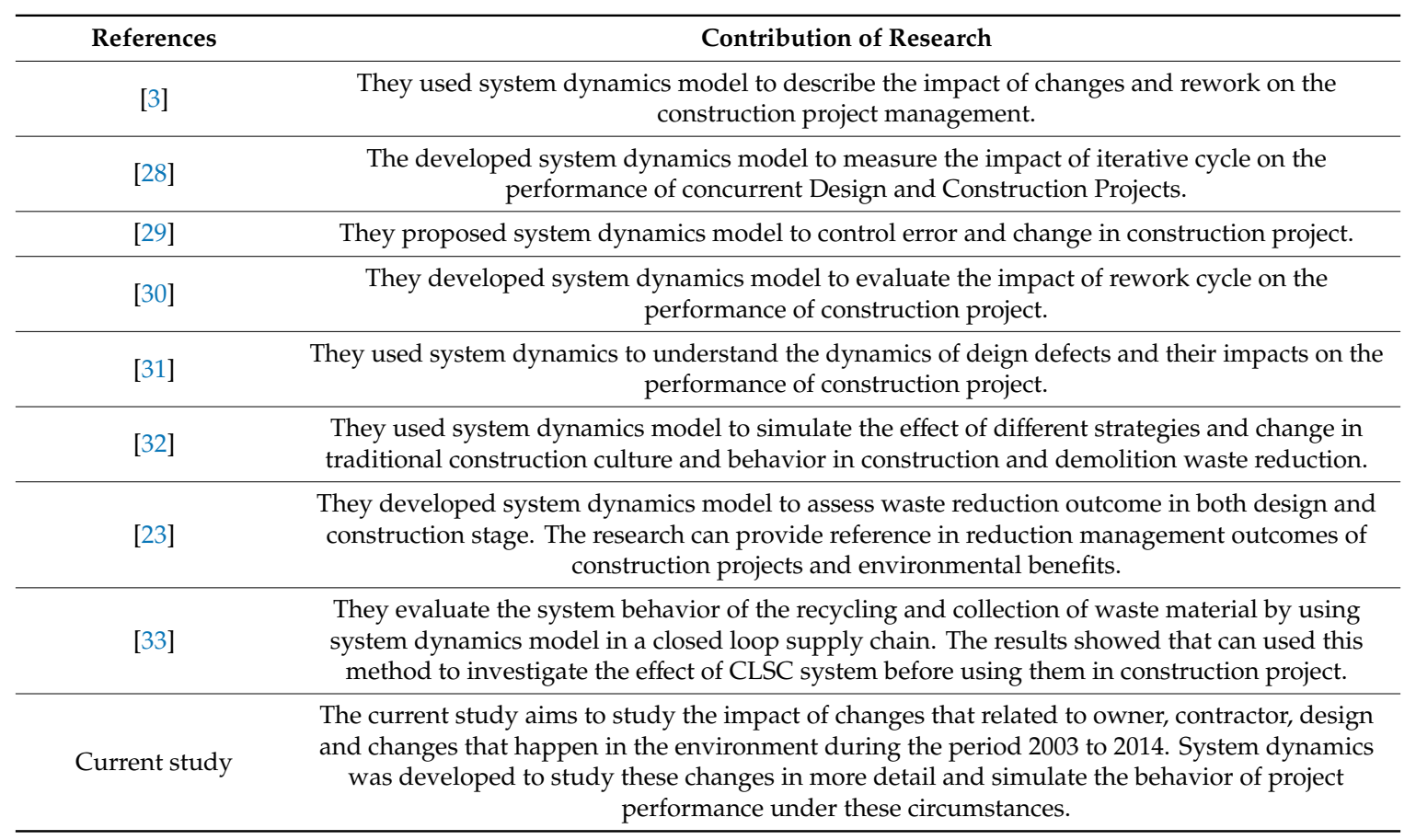

\subsection{Research Objectives}

This study aims to investigate the impact of change causes on the cost and time performance within the construction industry. These changes include the impact of owner, contractor, design defects, and modifications that occur in the surrounding legislative, economic, and security environment over the period 2003 to 2014. A comprehensive questionnaire is conducted on several construction projects that were established within Iraq region to implement this goal. The system dynamics model is developed to provide a deep insight perspective to the behaviour of complex process in a construction project. Additionally, the dynamic system model is performed to evaluate the level of performance in each legislation period. This is highly essential for construction project sustainability and management standpoints. 


\section{Methods}

\subsection{Introduction}

This research aims to investigate the overall cost and time performances of the construction projects and their behavior under the local abnormal circumstances that started in 2003 until now. The collected data included 30 projects that belong to government sector where they contribute to the benefit of the ministry of higher education. These projects are considered as a main project in Diyala University and are awarded during the period from 2003 until 2014. The reason behind choosing this period is that the 11 years period witnessed dramatic events that altered the surrounding circumstances in a way that deeply affected the construction industry. It was deemed reasonable to divide this period into four sub periods according to the legislative changes that were enacted by the legislative authorities in order to investigate the variation in the key influencing factors on construction projects, and consequently on the cost and time performances. This leads to classifying the four successive legislation periods, as follows: the first 2003-2006, the second 2007-2008, the third 2009-2011, and the fourth 2012-2014. In this research, the actual variation in projects time duration and the variation in projects cost are calculated for each project to represent the time and cost performance in all successive periods.

The questionnaire was conducted to give a quantitative estimation to the values of the internal variables that are represented here by the owner adequacy, contractor adequacy, the design defects, and the documentation conflicts. In addition, the questionnaire was designed to give an assessment to the owner impact on plan modifications and the impact of owner and contractor on the project workflow. Further, the questionnaire is provided a quantitative estimation to the values of the effect of the risky environment factors on the workflow process. Bear in mind, these factors are represented by the inflation, terrorism, and budget shortage.

The system dynamics model was developed in this research, in which the progress of the project is simulated. All of the external variables were dealt with as exogenous factors, while the internal variables were considered as endogenous factors. These factors were considered to abstract the values of the questionnaire outcome. All variables were represented as either stock, flow rate or auxiliary that is linked by influencing arrows. Both time and cost changes were resembled as accumulation stocks in this model and, by comparing these stocks values with the actual figures, the verification could be made after calibrating the auxiliary variables. Finally, the sensitivity analyses were conducted to determine the most effective and most appropriate variable by which the least modification can lead to the maximum enhancement of the project's overall performance. The finding of the current could be highly essential in assisting the decision makers for further modification in contractual terms and the conditions of cost and time performance.

\subsection{Mathematical Formulations}

In order to establish the cost and time schedule performances, the following formulas are used:

i. The cost change is the difference between the total cost at the project completion and the original budget [34].

$$
\text { Cost change }=\frac{\text { total expense }- \text { budget }}{\text { budget }} \times 100 \%
$$

ii. The time schedule change is the difference between the time used to complete the project and the contract time [34].

$$
\text { Time change }=\frac{\text { total duration }- \text { contract time }}{\text { contract time }} \times 100 \%
$$




\subsection{Data Collection}

The collected data of the 30 construction projects that were distributed among the four legislative periods were examined for the cost and time change, according to Equations (1) and (2). Table 2 lists the results.

Table 2. Cost and time change in each legislation period.

\begin{tabular}{cccc}
\hline Legislative Period & Duration & Cost Change \% & Time Schedule Change \% \\
\hline 1 & $2003-2006$ & 16.85 & 205.37 \\
2 & $2007-2008$ & 9.62 & 156.36 \\
3 & $2009-2011$ & 8.61 & 113.1 \\
4 & $2012-2014$ & 8.53 & 66.67 \\
\hline
\end{tabular}

In order to obtain a quantitative assessment of the various variables that affect the progress of the construction projects, a questionnaire was made to this purpose. The questionnaire was distributed to different populations, which include the managers, engineers, and the main stakeholders of these projects, about 15 experts whom are involved in each project of the collected survey.

The questionnaire is divided into three parts. The first one is provided data regarding the personal profile of the surveyed respondents. It contains general information regarding the professions, educational attainment, engineering specialization, and working experience. The second part provided a quantitative estimation for the project internal variables, such as owner adequacy, contractor adequacy, design defects, and documentation conflict. In addition, this part provides assessments to the impact of owner adequacy on the plan modification and project workflow. Further, the second part contains the impact of contractor adequacy on the project on the project workflow. The third part of questionnaire estimated the impact of the risky environment conditions that are represented by inflation, terrorism, and budget on the project's workflow. The questionnaire was distributed to pilot study before being used in the real sample. The size of pilot study ranged between 30 and 50 respondents [35]. The authors selected 40 respondents that were collected and arranged to discover the problem and identify the questions that are more ambiguous than others and this helps the authors to take corrective practice that improve the research process. The questionnaire form included a premeditated range for each variable assessment and the highest votes of values were obtained from the results of the questionnaire, as in Tables 3-5.

Table 3. Suggested value for internal variables.

\begin{tabular}{ccccc}
\hline Legislative Period & $\begin{array}{c}\text { Owner } \\
\text { Adequacy\% }\end{array}$ & $\begin{array}{c}\text { Contractor } \\
\text { Adequacy \% }\end{array}$ & $\begin{array}{c}\text { Design } \\
\text { Defects\% }\end{array}$ & $\begin{array}{c}\text { Conflict between } \\
\text { Contract Document\% }\end{array}$ \\
\hline 1 & $44-55$ & $44-55$ & $6-9$ & $6-7.5$ \\
2 & $56-66$ & $44-55$ & $3-6$ & $2.6-5$ \\
3 & $66-77$ & $56-66$ & $0-3$ & $0-2.5$ \\
4 & $78-88$ & $78-88$ & $0-3$ & $0-2.5$ \\
\hline
\end{tabular}

Table 4. Estimated impacts on plan modifications and workflow.

\begin{tabular}{cccc}
\hline Legislative Period & $\begin{array}{c}\text { Impact of Owner on the } \\
\text { Plan Modification \% }\end{array}$ & $\begin{array}{c}\text { Impact of Owner on the } \\
\text { Project Workflow\% }\end{array}$ & $\begin{array}{c}\text { Impact of Contractor on } \\
\text { the Project Workflow \% }\end{array}$ \\
\hline 1 & $0-6$ & $55-66$ & $55-66$ \\
2 & $0-6$ & $55-66$ & $55-66$ \\
3 & $24-30$ & $66-77$ & $66-77$ \\
4 & $12-18$ & $88-100$ & $88-100$ \\
\hline
\end{tabular}


Table 5. Suggested values of the impact of risky environment conditions.

\begin{tabular}{cccc}
\hline Legislative Period & Inflation $\%$ & Terrorism $\%$ & Budget Shortage $\%$ \\
\hline 1 & $22-33$ & $11-22$ & $22-33$ \\
2 & $33-44$ & $22-33$ & $33-44$ \\
3 & $55-66$ & $44-55$ & $66-77$ \\
4 & $88-100$ & $77-88$ & $88-100$ \\
\hline
\end{tabular}

Figure 1 describes the phases of collection data, questionnaire, and preparation of the input variable. Figure 1 shows the methodology of research and the variable that used as input to system dynamics model.

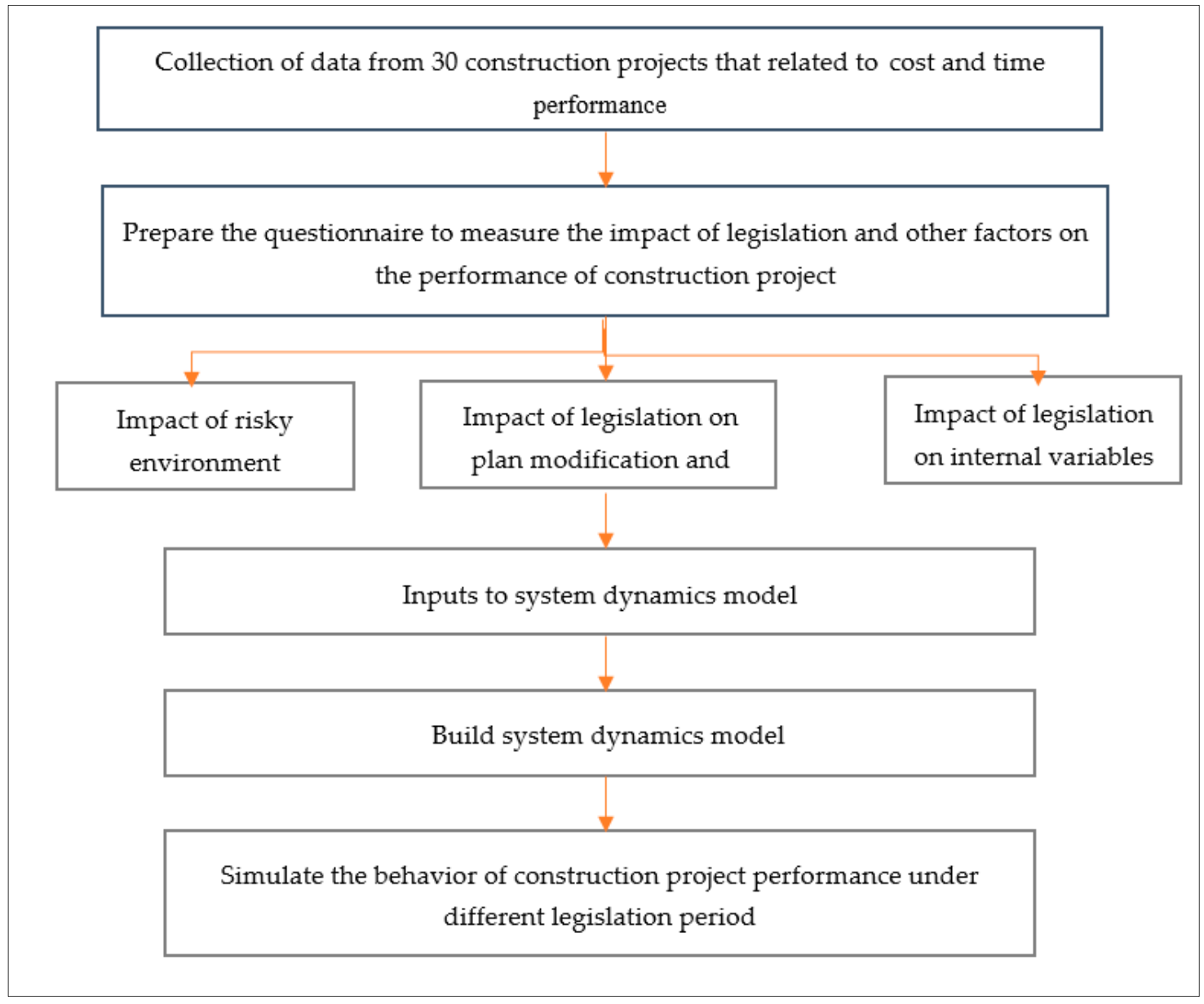

Figure 1. Flow chart of the proposed research methodology.

\subsection{Development of System Dynamics Model}

The model is simply developed depending on the available cost and time related data of the group of projects that are included in this study. It may represent the iterative cycle of plan or work changes in local projects construction [36]. The role of the system dynamics model is to simulate the dynamic relations between the various elements and the factors that affect the progress of the project throughout its duration [37]. Either stocks, flows, or auxiliaries emulate these variables. The simulation in this model was established mainly by tracking task flowing as shown in Figure 2. The value of each stock represents the cost of the items that are contained in it. 


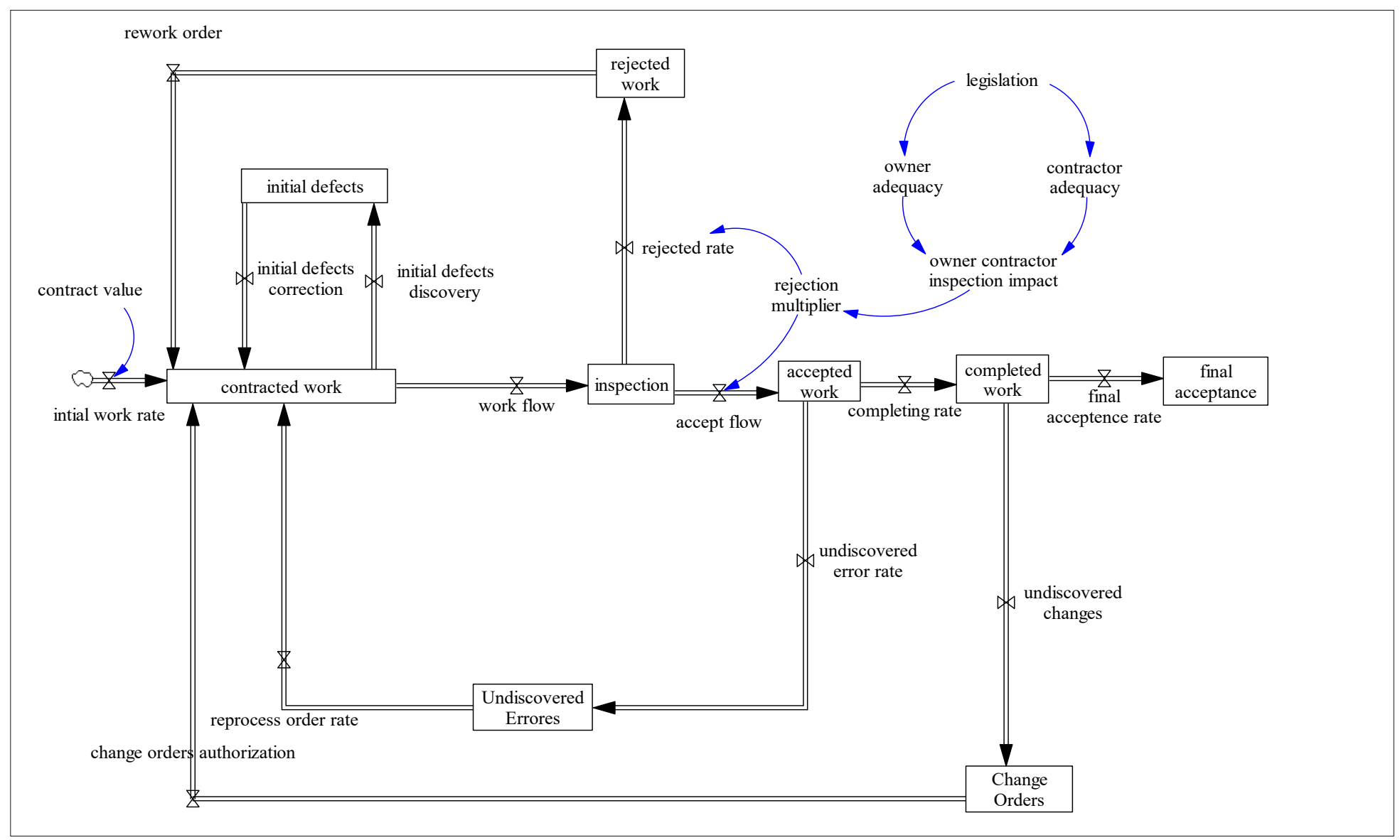

Figure 2. The proposed system dynamics model. 
Figure 2 describes the system dynamics model that was used in this research. The first phase is the "contracted work", which represents the value of the total work items that the contractor is obligated to complete. These items include the original items of the basic contract in addition to the reinitiated items.

The original items are interred by the flow rate "initial work rate", which adopt the "Pulse" function for obtaining the most realistic simulation to the procedure by which the obligation on the contractor is taking place. Locally, the contractor is given a period of fourteen days to commence the work and all of his obligations are immediately due [38]. This process could be best simulated by the "Pulse" function.

On the other hand, the reinitiated items are generated by the following:

1- The accumulated items as obligation on the contractor in the "contracted work" stock is dispersed through the flow rate "workflow" that convey the tasks or obligations to the "inspection" stock.

2- The initial defects that are mainly related to the original errors either in the bill of quantities due to miscalculation or estimation or due to discrepancies in designs. These defects are often discovered at the early beginnings of the project commence [14]. The accumulated values of these defects are computed in the "initial defects" stock and are reconsidered as obligation items at the rate of "initial defects correction", which governs the flow of items between the stocks of "initial defects" and "contracted work".

3- The "workflow" rate is affected by the external risky environment factors, such as inflation, terrorism, and budget shortage, as well as the internal factors, such as owner adequacy and contractor adequacy, which both vary a great deal according to the legislative period. The effect of these factors varies with the time ratio, which represents the remaining time divided by the total contract time.

4- The raw materials to be supplied as well as every work item to be accomplished must be inspected for quality assurance. This process is simulated in the accumulation in the "inspection" stock in which the item is either accepted. In this case, it is dispersed through the "accept flow" rate to the "accepted work" stock and goes on or rejected being transferred through the "rejection" rate to the "rejected work" stock to be reinitiated once again [39]. The amount of rejected work is dependent on owner adequacy and contractor adequacy, which legislation constrains.

5- The rejected works simulated by transferring these items to the stoke "rejected work" and then reinitiating them by issuing by issuing rework orders, as done in the rate "rework orders" by which these rejected items are flown back to the stock "contracted work".

6- The stock "accepted work" represents all of the completed and accepted items that are mostly transferred to the "completed work" stock by the flow rate "accepting rate.

7- The undiscovered requirements that often lately emerge mostly due to neglecting certain aspects in the design phase or the presence of some sort of conflict between the documents of the contract that do not materialize until the completion of some stages in the project [14]. Such items usually arise as a percentage of the accepted work that may require ordering the initiation of the required items that are represented in the stock "undiscovered errors". These items are transferred to the "contracted work" stoke at the rate of the "reprocess order rate".

8- The change orders that includes all newly added groups of items either due to emerging needs to augment certain recently completed parts of the project or due to a request by the owner to fulfill its own requirements.

9- The "completing rate" flows into the stock "completed work" in which all of the competed and accepted items are accumulated, and no action should be taking on them until the final acceptance, unless some major change orders are issued that will definitely affect some of the completed and accepted items.

10- The final stock is the "final acceptance", in which all of the completed and accepted items are accumulated after the issuing of the final acceptance certificate of the project. The total cost 
accumulated in this stock represents the final cost of the project and the project legally terminates when the value of this stock reaches the total summation of the contract cost, plus the total cost of the additional change orders.

11- The change in time is then determined by subtracting the value of contract duration from the duration that is required to implement the project that is mathematically calculated in the auxiliary "conclusion reference", and the difference is then divided on the value of contract duration [40].

\subsection{Model Calibration and Validation}

By simulating the system dynamics model, quite a variety of inputs were used to test the applicability of the model. The outcomes that were obtained from the questionnaire are entered to the system dynamics model to evaluate the cost and time performance in construction projects.

The results of the model are then compared with the results that were obtained from the collected data to test the validity of the model. The comparison between these results are tabulated in Tables 6 and 7.

Table 6. Comparison between actual and simulated cost change.

\begin{tabular}{ccccc}
\hline Legislation & Period & $\begin{array}{c}\text { Actual Cost } \\
\text { Change \% }\end{array}$ & $\begin{array}{c}\text { Simulated Cost } \\
\text { Change \% }\end{array}$ & Difference \\
\hline 1 & $2003-2006$ & 16.85 & 17.7 & $0.85 \%$ \\
2 & $2007-2008$ & 9.62 & 10.2 & $0.58 \%$ \\
3 & $2009-2011$ & 8.61 & 8.75 & $0.14 \%$ \\
4 & $2012-2014$ & 8.53 & 7.87 & $0.66 \%$ \\
& \multicolumn{2}{c}{ Average } & & $0.55 \%$ \\
\hline
\end{tabular}

Table 7. Comparison between actual and simulated schedule change.

\begin{tabular}{ccccc}
\hline Legislation & Period & $\begin{array}{c}\text { Actual Schedule } \\
\text { Change } \%\end{array}$ & $\begin{array}{c}\text { Simulated Schedule } \\
\text { Change } \%\end{array}$ & Difference \\
\hline 1 & $2003-2006$ & 205.37 & 196 & $9.37 \%$ \\
2 & $2007-2008$ & 156.36 & 157.36 & $1 \%$ \\
3 & $2009-2011$ & 113.1 & 110.22 & $2.9 \%$ \\
4 & $2012-2014$ & 66.67 & 70.45 & $3.78 \%$ \\
& & Average & & $4.24 \%$ \\
\hline
\end{tabular}

\section{Research Results and Discussion}

The simulation of the model is visualized using VENSIM PLE software package and the results revealed the relation between legislation with respect to the internal factors and the impact of variables on the project performance, as shown in Figures 3 and 4, respectively. 


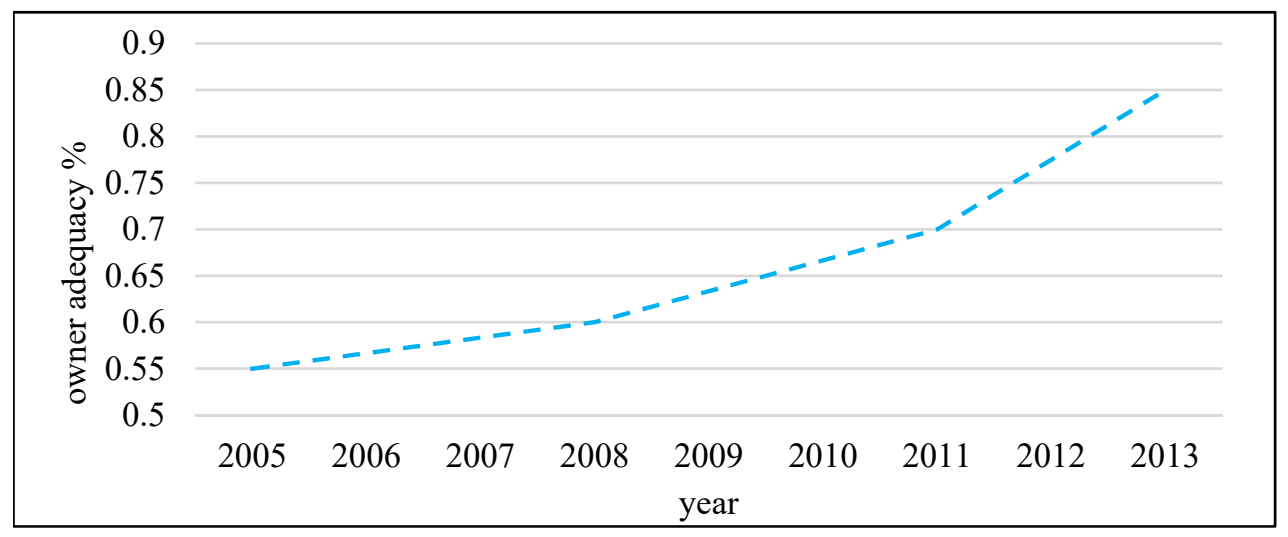

(a)

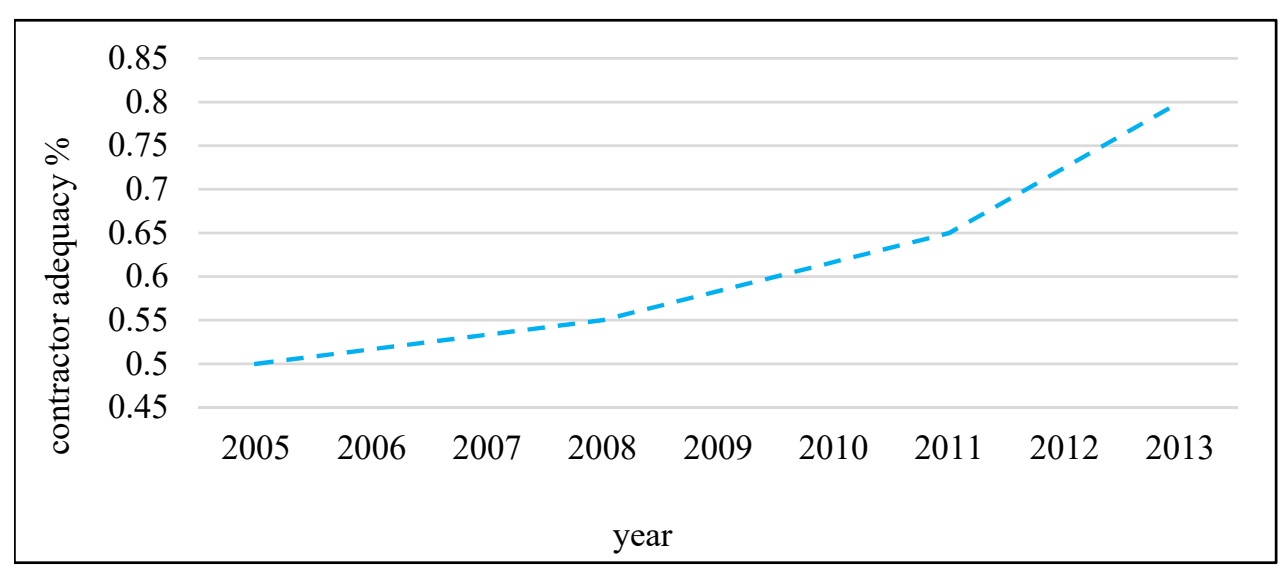

(b)

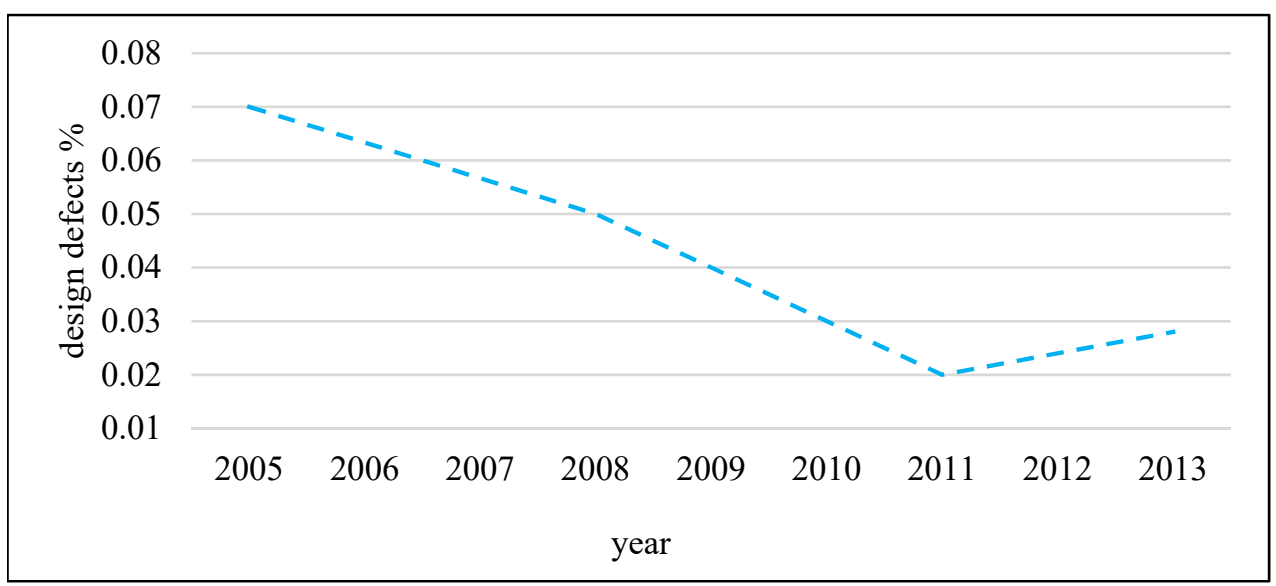

(c)

Figure 3. Cont. 


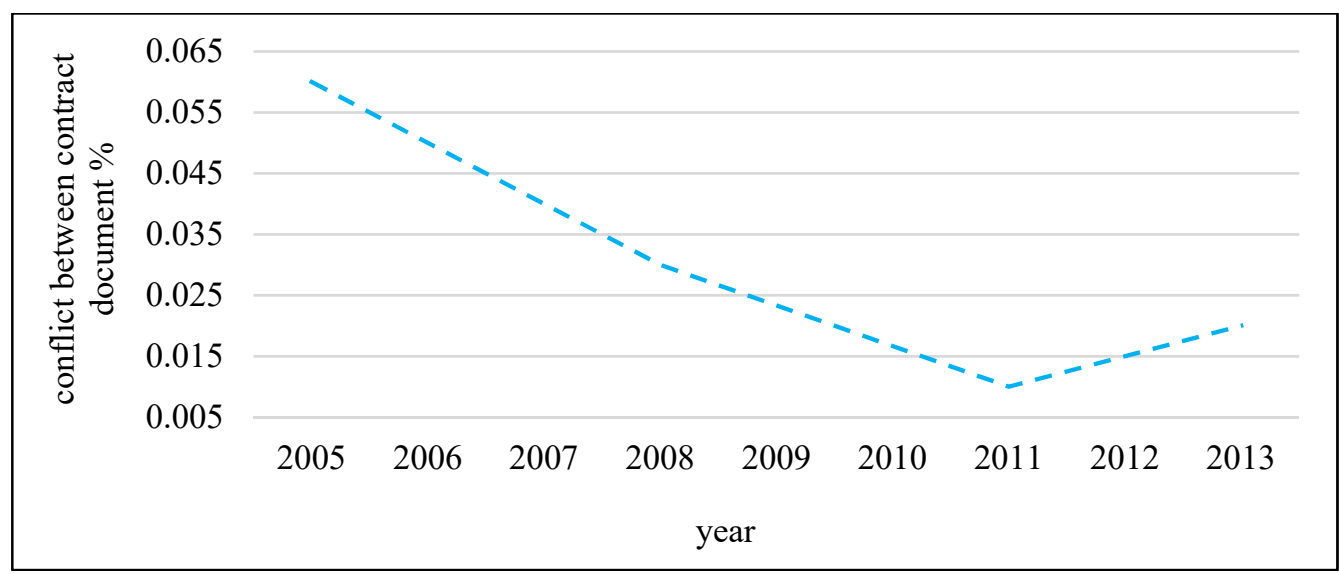

(d)

Figure 3. (a) Change of owner adequacy with legislative periods, (b) Change of contractor adequacy with legislative periods, (c) Change of design defects with legislative periods, and (d) Change of conflict between contract documents with legislative period.

Figure 3 demonstrates the relationship between owner adequacy, contractor adequacy, design defects, and conflict in contract documents with the legislation change. The results showed that the change in legislation lead to an increase the owner adequacy and contractor adequacy that affects phases of construction process, as shown in Figure 3a,b. The change in legislation affects the design process by reducing the amount of design defects and the conflict in contract document (See Figure 3c,d). These changes enhance the performance of the construction project in terms of cost and time.

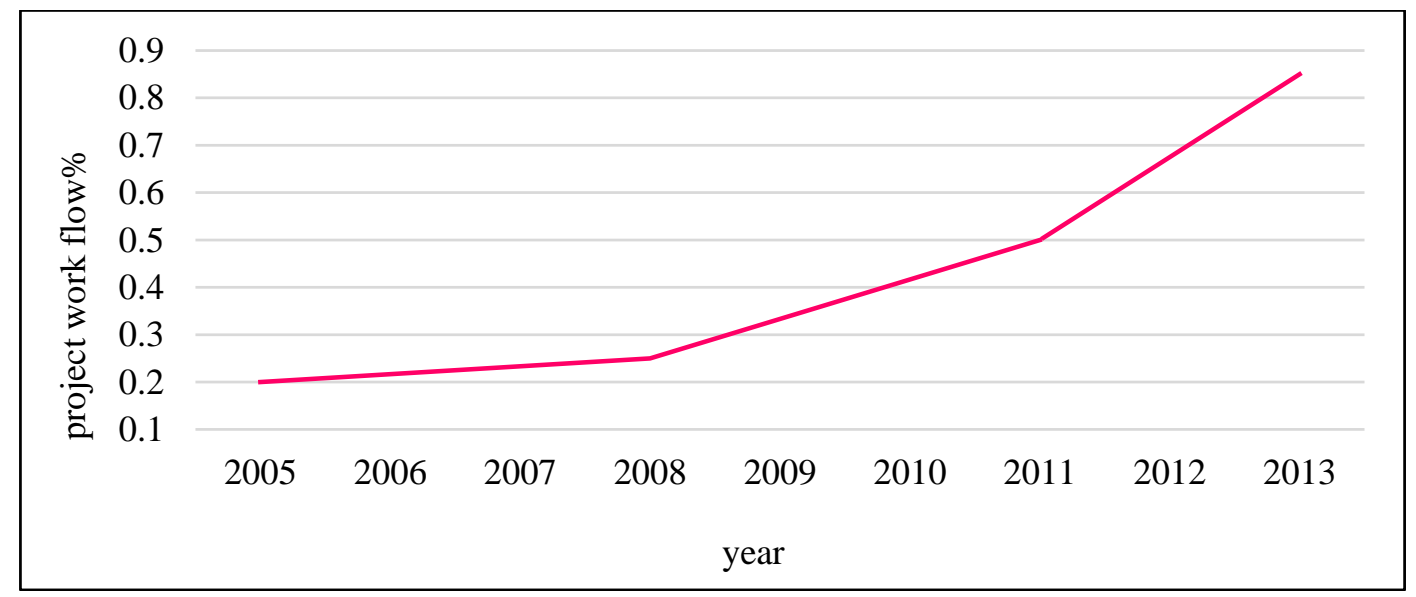

(a)

Figure 4. Cont. 


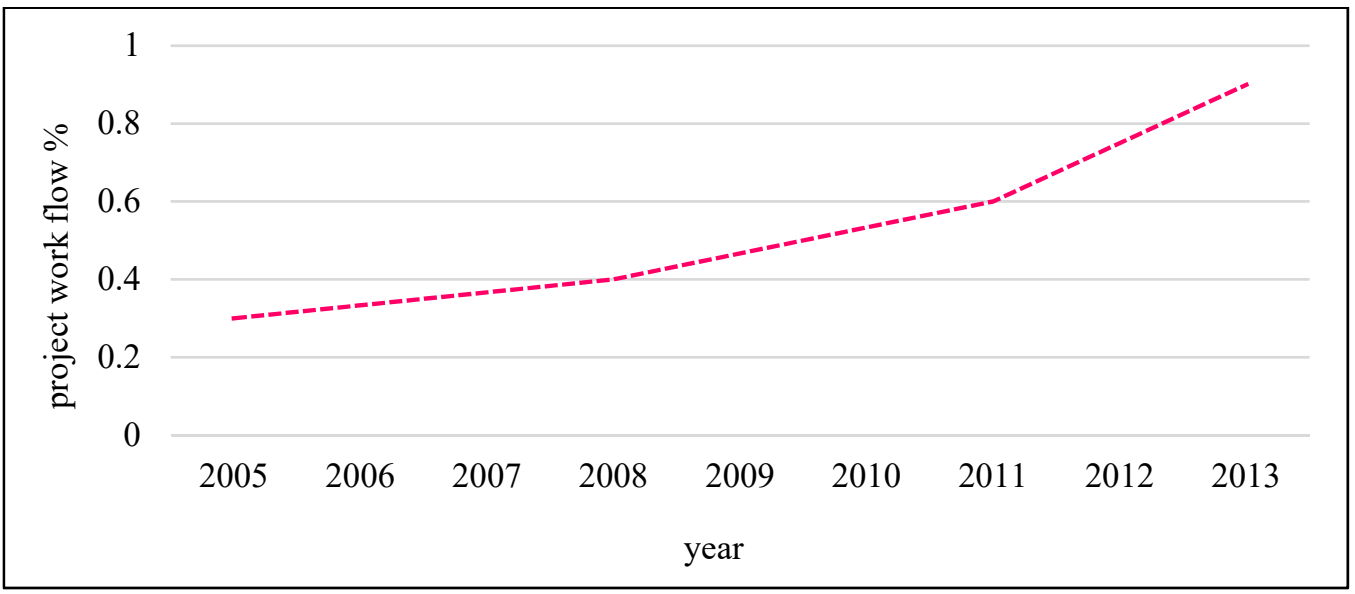

(b)

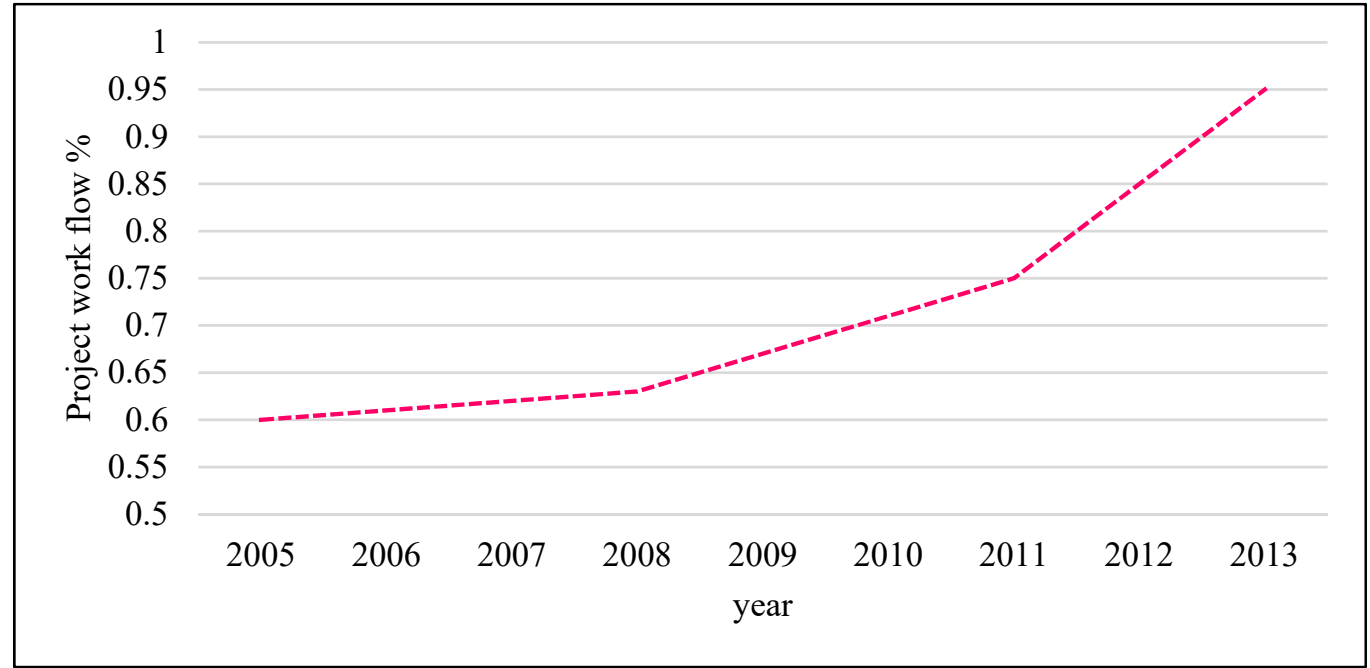

(c)

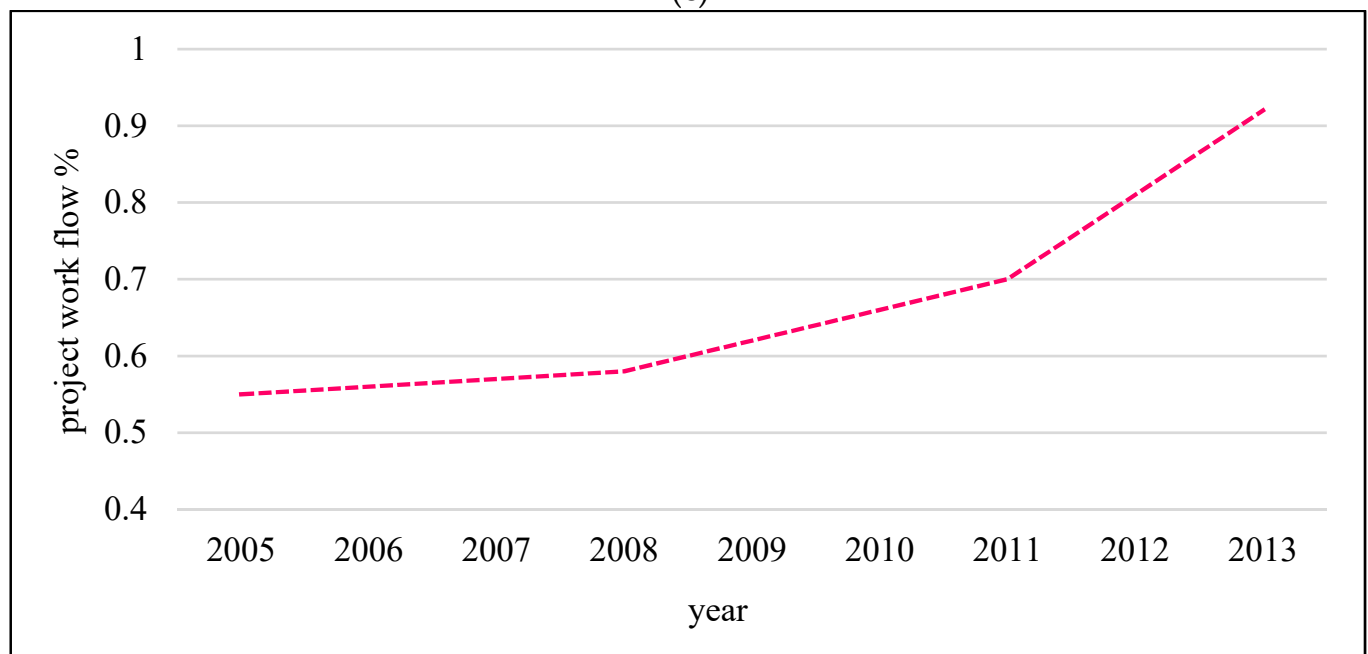

(d)

Figure 4. (a) Change in the project workflow under terrorism impact, (b) Change in the project workflow under inflation impact, (c) Change in the project workflow under owner impact, and (d) Change in the project workflow under contractor impact. 
Figure 4a,b showed the change in the project workflow over the investigated period 2003-2014 under the surrounding environmental factors. The results revealed the huge impact of the events that were experienced during the study period on the project workflow. These events are decreased after 2005, and this leads to enhance the time performance of the construction project. Figure 4c,d illustrated the impact of owner and contractor on the project workflow. The results indicated that the project workflow increased by the increment of the owner and contractor adequacy. These results can be discussed by the change in the legislation, which leads to increasing the efficiency of owner and contractor's selection process and this certainly affects the performance of a construction project. Figure 5 a shows this pattern of cost change with respect to the legislation periods. The results of the collected data from construction projects that dealt with the change in project cost, revealed a notable reduction in cost change for the construction projects as the legislations were progressively changed. During the first examined period (2003-2006), the change in project cost calculated as $16.85 \%$ / Whereas, in the second period (2007-2008), the cost change was decreased by $7.23 \%$ to become $9.62 \%$. The level of cost change calculates in the third and fourth periods (2009-2011 and 2012-2014) were $8.61 \%$ and $8.53 \%$, respectively.

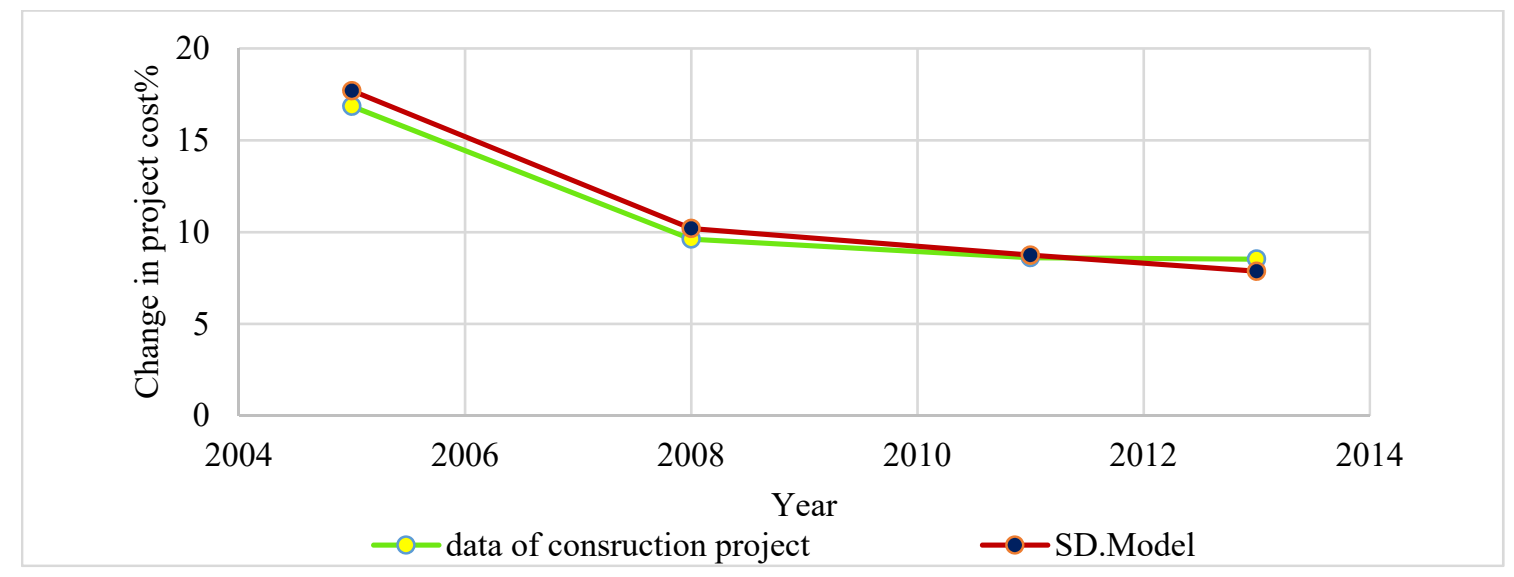

(a)

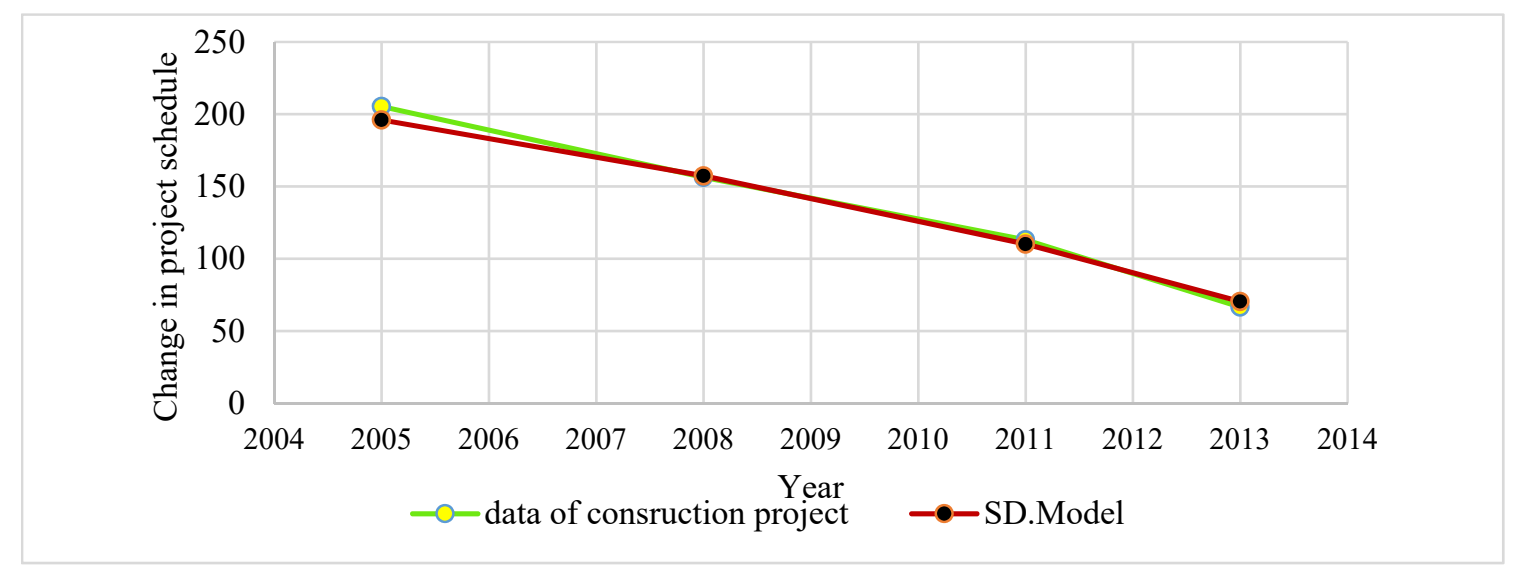

(b)

Figure 5. (a) Change in cost deficiency with legislative periods, (b) Change in schedule deficiency with legislative periods.

The results also revealed an obvious decrease in schedule change for the construction projects as legislations were progressively changed. During the first period from (2003-2006), the change in the project schedule calculated was as $205.37 \%$, while in the second period (2007-2008), the schedule 
change was decreased by $49.01 \%$ to become $156.36 \%$. The levels of schedule change calculated in the third and fourth periods (2009-2011 and 2012-2014) were $113.1 \%$ and $66.67 \%$, respectively. Figure $5 \mathrm{~b}$ shows this pattern of project schedule change with respect to the legislations periods.

The results that were obtained from the system dynamics model revealed that the enhancement behavior of project cost and schedule performance in a similar pattern. By running the model, the behavior of each factor is considered, and the main outcomes, as represented in cost and schedule estimate, were very close to the findings of the data that was collected from construction projects. The cost changes estimations for the first period through the fourth one were $17.7 \%, 10.2 \%, 8.75 \%$, and $7.87 \%$, respectively. The schedule changes estimation for the first period through the fourth one were $196 \%, 157.36 \%, 110.22 \%$, and $70.45 \%$, respectively. The closeness between the finding that was obtained from construction project and those of the system dynamics model throughout the study period could be reflected by the average difference, which is found to be $0.55 \%$ and $4.24 \%$, as listed in Tables 5 and 6 .

Figure 6a shows the defects behavior for each examined legislation. The initial defects and undiscovered errors showed tangible reductions in each legislation period, except in the fourth one, in which the value of these defects indicated an increase over that of the third legislative period, as shown in Figure $6 \mathrm{a}, \mathrm{b}$. The change order behavior demonstrates a decrease in the second legislation. However, the third and fourth legislations period showed an increment in its value (See Figure 6c). The rejected work behavior exhibited a gradual decrease in value, which descended from the first legislation period through the fourth (see Figure 6d). The final project cost presented a gradual noticeable increment in the value from the first legislation through the fourth (see Figure 6e).

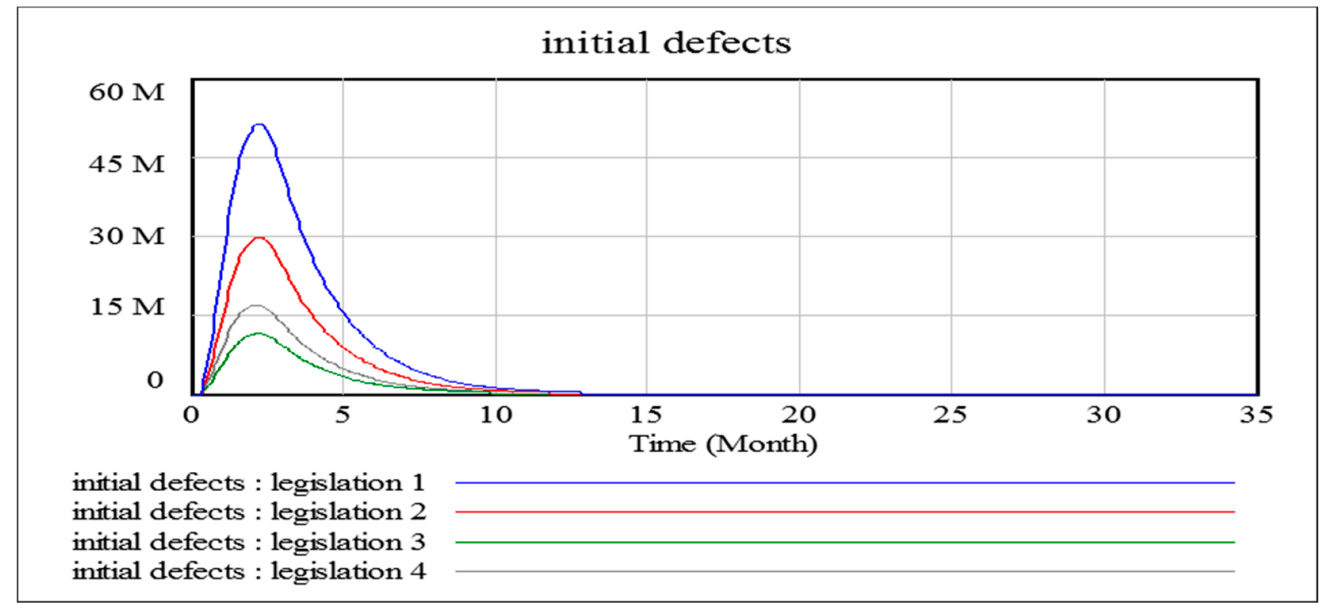

(a)

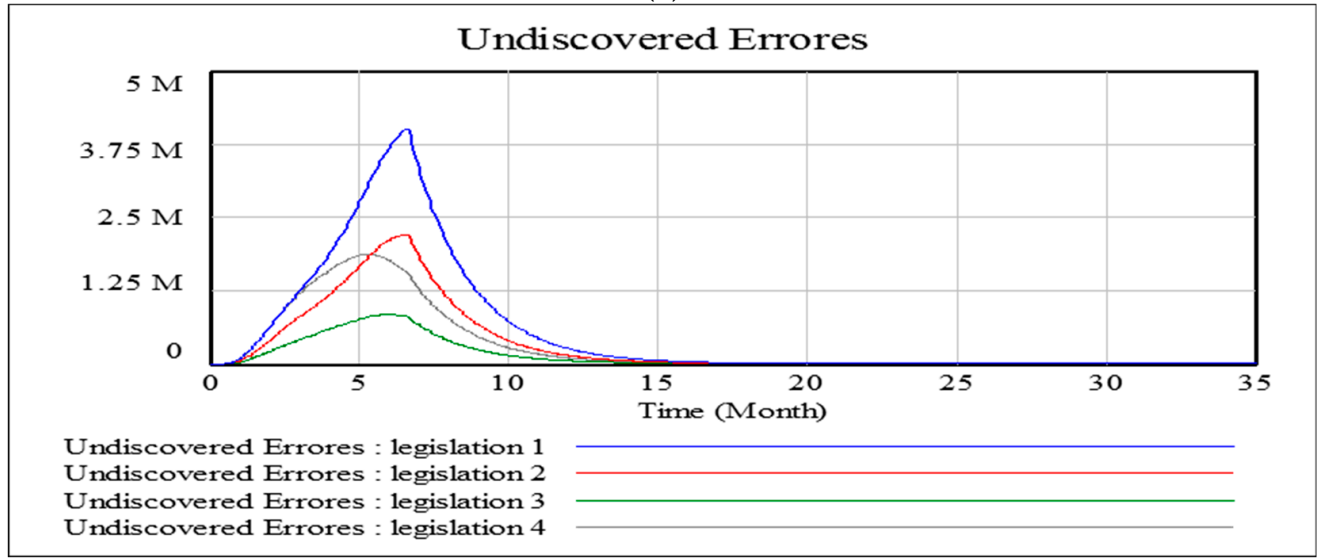

(b)

Figure 6. Cont. 


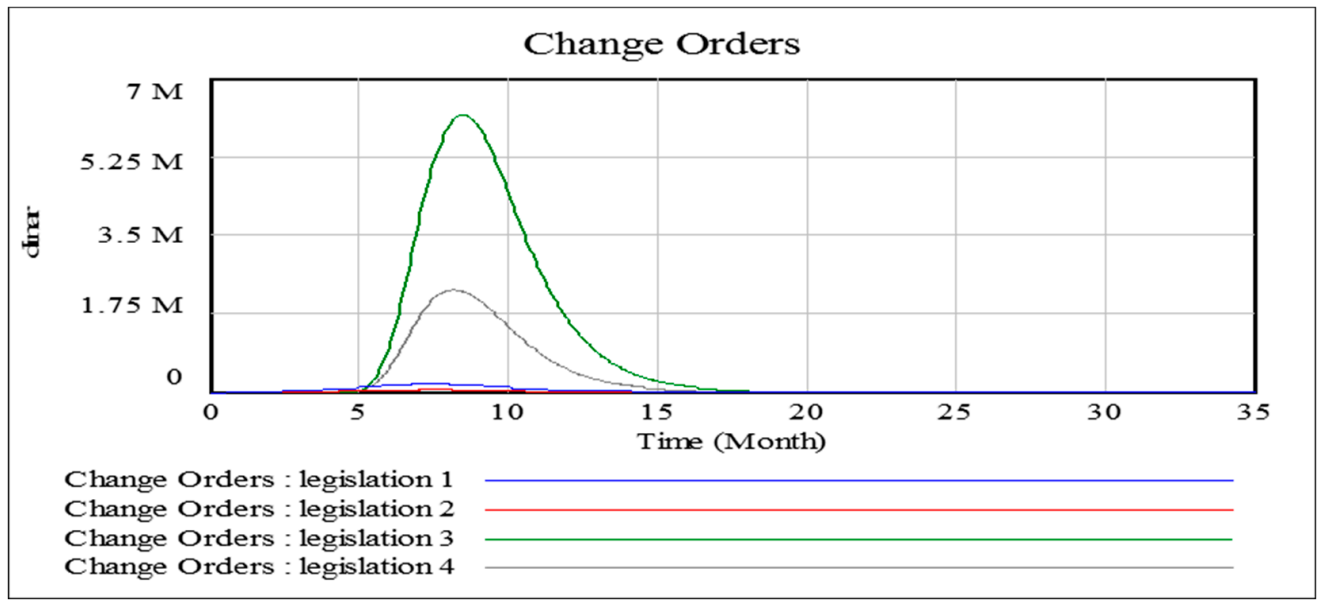

(c)

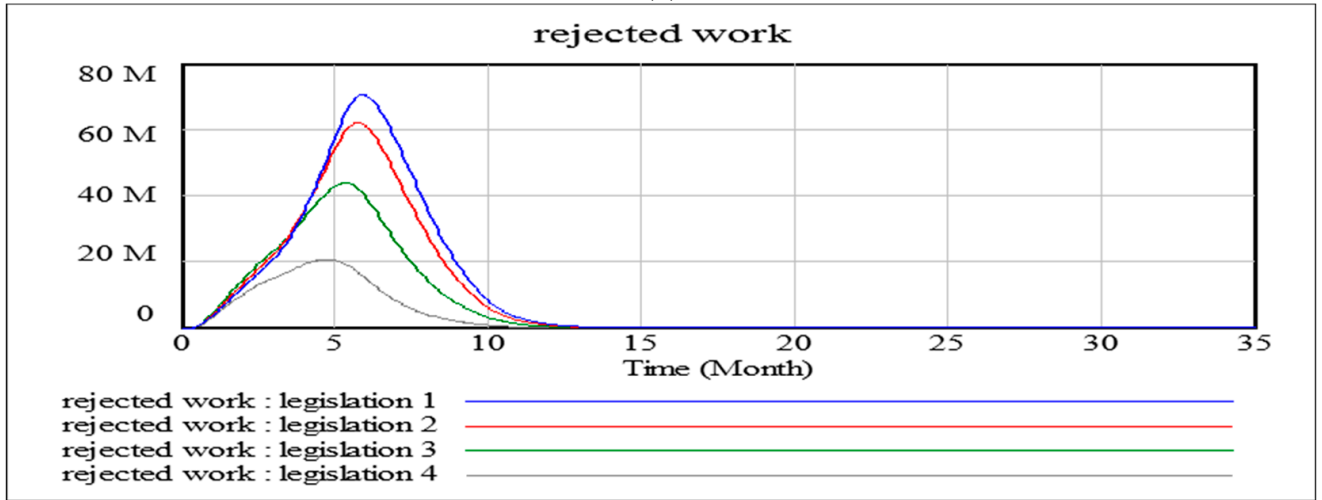

(d)

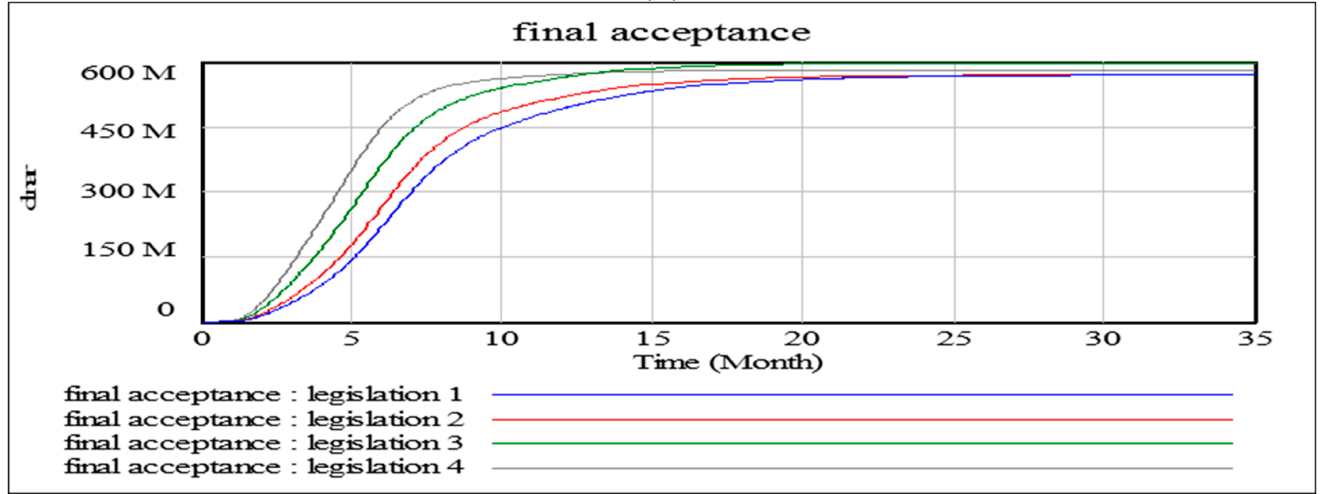

(e)

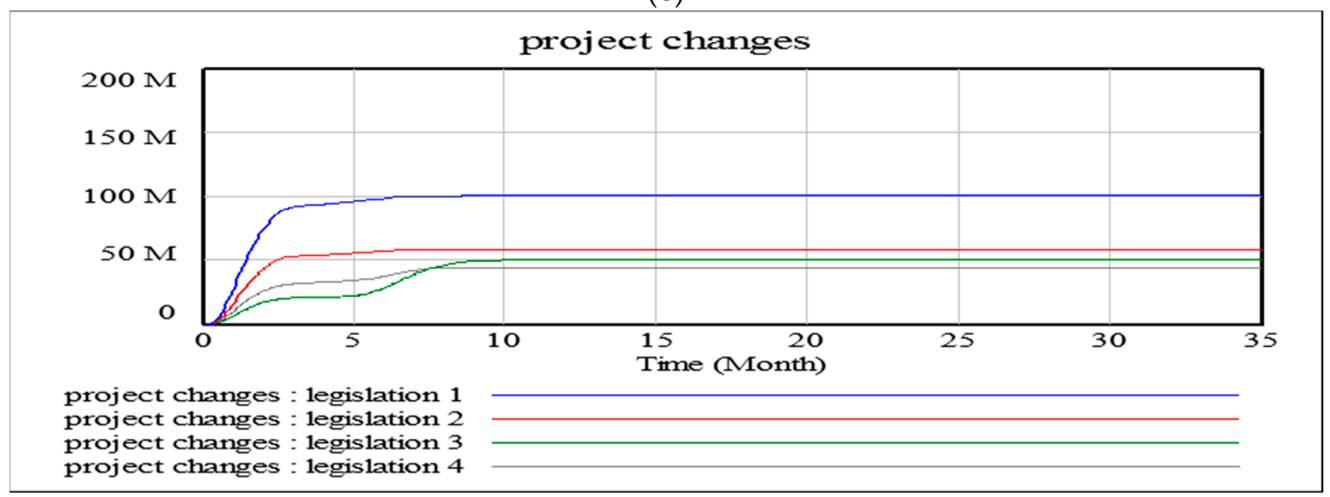

(f)

Figure 6. Cont. 


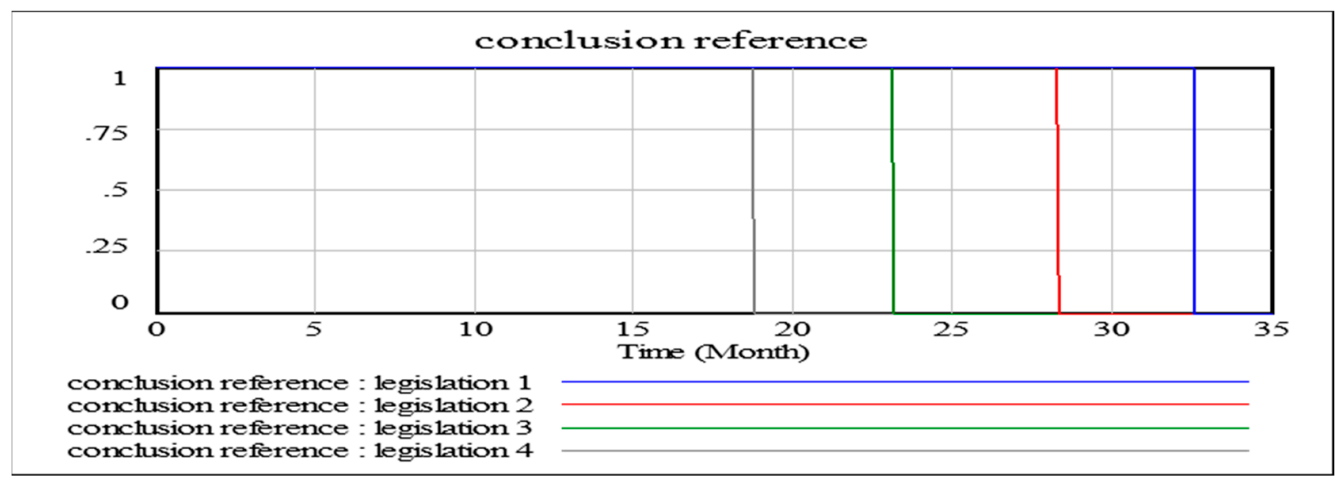

$(\mathrm{g})$

Figure 6. (a) Initial defect value in all legislations, (b) Undiscovered errors accumulation value in all legislation, (c) Change orders value in all legislations, (d) rejected work value in all legislation, (e) final project cost value in all legislation, (f) Project changes value in all legislations, (g) Final project time duration value in all legislations.

The value of project changes displayed a decreasing in their values from the first legislation through the fourth (see Figure $6 \mathrm{f}$ ). Whereas, the final project time duration behavior disclosed a noticeable reduction in value from legislation 1 to legislation 4 , as illustrated in Figure $6 \mathrm{~g}$. Overall, the results showed an improvement in construction project performance for the examined eleven years period. This progress in the project performance can reflect the changing that happened on the factors that control the management of construction projects. The proposed model evidenced an excellent strategy to evaluate the performance of construction project under changeable surrounding variables. It is worth mentioning the system dynamics that were used in this research to demonstrate the relation between legislation with respect to the surrounding environment factor, the internal project factors, and their impact on the construction project performance. Using this model enables the decision maker to take the proper decision by helping him to find the defects in each phase in the construction process and discover which factor has high impact on the project performance.

\section{Conclusions}

In this paper, the level of cost and time performance in local construction projects was evaluated under various changing factors in the surrounding environment in the Iraqi construction industry. A questionnaire was used and the dynamic system model was developed to illustrate the relation between the internal factors that affect project performance and changes in the surrounding events include legislative, economic, and security environment during the period that lasted from 2003 to 2014. The data was collected from 30 construction projects that were awarded during the period from 2003 until 2014. The questionnaire was used to estimate the values for the impact of internal factors concerning both the owner and the contractor, with special consideration to their variation through successive legislation periods. These estimates were utilized in a system dynamics model, in which the project development process is simulated. The actual cost change values were $16.85 \%$, $9.62 \%, 8.61 \%$, and $8.53 \%$, respectively. The developed model returned the project cost change values of $17.7 \%, 10.2 \%, 8.75 \%$, and $7.87 \%$ for the four successive legislative periods. In addition, the model returned the project time changes of $196 \%, 157.36 \%, 110.22 \%$, and $70.45 \%$. While the actual time changes were $205.37 \%, 156.36 \%, 113.1 \%$, and $66.67 \%$ for the same successive periods. These estimates showed a progressive reduction of $10.9 \%$ for the change in project cost and $135.37 \%$ for the change in project schedule throughout the eleven years period. The developed model approved its potential for estimating the change in the cost and time performance for all of the construction projects.

Author Contributions: Conceptualization, Z.A.; Formal analysis, W.J., Z.A. and Z.Y.; Investigation, Z.A.; Methodology, Z.A.; Project administration, Z.Y.; Software, Z.A.; Supervision, H.N. and R.Z.; Writing - original draft, Z.A. and Z.Y.; Writing - review \& editing, W.J., N.A.-A. and Z.Y. 
Conflicts of Interest: The authors have no research conflict to disclose with regards to publish this research.

\section{References}

1. Vorakulpipat, C.; Rezgui, Y.; Hopfe, C.J. Value creating construction virtual teams: A case study in the construction sector. Autom. Constr. 2010, 19, 142-147. [CrossRef]

2. Memon, A.H.; Abdul Rahman, I.; Abdul Azis, A.A. Preliminaries Study on Causative Factors Leading to Construction Cost Overrun. Int. J. Sustain. Constr. Eng. Technol. 2011, 2, 57-71.

3. Love, P.; Mandal, P.; Smith, J. Modelling the dynamics of design error induced rework in construction. Constr. Manag. Econ. 2000, 18, 567-574. [CrossRef]

4. Sun, M.; Meng, X. Taxonomy for change causes and effects in construction projects. Int. J. Manag. 2009, 27, 560-572. [CrossRef]

5. Erdogan, B.; Anumba, C.; Bouchlaghem, D.; Nielsen, Y. Change Management in Construction: The Current Context. In Proceedings of the 21st Annual ARCOM Conference, London, UK, 7-9 September 2005; pp. 1085-1095.

6. Hsieh, T.; Lu, S.; Wu, C. Satistical analysis of causes for change orders in metropolitan works. Int. J. Proj. Manag. 2004, 22, 679-686. [CrossRef]

7. Wu, C.; Hsieh, T.; Cheng, W. Statistical analysis of causes for design change in highway construction on Taiwan. Int. J. Manag. 2005, 23, 554-563. [CrossRef]

8. Ahmed, H.; Yusuff, R. Factors Affecting Quality During The Construction Phase in Iraqi Government Companies. Int. J. Appl. Eng. Res. 2016, 11, 7974-7981.

9. Naji, H.; Ibrahim, A.; Hassan, Z. evaluation of legislation adequacy in managing time and quality performance in construction projects-A bayesian decision tree approach. Civ. Eng. J. 2018, 4, 993.

10. Zhao, Z.Y.; Lv, Q.L.; Zuo, J.; Zillante, G. Prediction system for change management in construction project. J. Constr. Eng. Manag. 2009, 136, 659-669. [CrossRef]

11. Iyagba, R.O.; Ijaola, I.A. A comparative study of causes of change orders in public construction project in Nigeria and Oman. J. Emerg. Trends Econ. Manag. Sci. 2012, 3, 495-501.

12. Elawi, G.; Algahtany, M.; Sullivan, K. Major Factors Causing Construction Delays in Mecca. J. Adv. Perform. Inf. Value 2015, 31, 7 .

13. Al-Ageeli, H.; Alzobaee, A.S. The Most Influential Factor on the Stumble and Failure of the governmental Projects. J. Eng. 2016, 22, 93-110.

14. Naji, H.; Zehawi, R.; Hasan, Z. Managing Quality performance by Legislation in Iraqi Construction Projects: A system Dynamics Approach. J. Eng. Appl. Sci. 2018, 13, 8511-8519.

15. Rodrigues, A.; Williams, T. System dynamics in project management: Assessing the impacts of client behaviour on project performance. J. Oper. Soc. 1998, 49, 2. [CrossRef]

16. Park, M.; Peña-Mora, F. Dynamic change management for construction: Introducing the change cycle into model-based project management. Syst. Dyn. Rev. 2003, 19, 213-242. [CrossRef]

17. Lee, S.H.; Peña-Mora, F.; Park, M. Dynamic planning and control methodology for strategic and operational construction project management. Autom. Constr. 2006, 15, 84-97. [CrossRef]

18. Elbeltagi, E.; Hegazy, T.; Eldosouky, A. Dynamic layout of construction temporary facilities considering safety. J. Constr. Eng. Manag. 2004, 130, 534-541. [CrossRef]

19. Lyneis, J.; Cooper, K.; Els, S. Strategic management of complex projects: A case study using system dynamics. Syst. Dyn. Rev. 2001, 17, 237-260. [CrossRef]

20. Lyneis, J.; Ford, D. System dynamics applied to project management: A survey, assessment, and directions for future research. Syst. Dyn. Rev. 2007, 23, 157-189. [CrossRef]

21. Shen, L.Y.; Wu, Y.Z.; Chan, E.H.W.; Hao, J.L. Application of system dynamics for assessment of sustainable performance of construction projects. J. Zhejiang Univ. Sci. A 2005, 6, 339-349. [CrossRef]

22. Love, P.E.D.; Holt, G.D.; Shen, L.Y.; Li, H.; Irani, Z. Using systems dynamics to better understand change and rework in construction project management systems. Int. J. Proj. Manag. 2002, 20, 425-436. [CrossRef]

23. Ding, Z.; Zhu, M.; Tam, V.W.Y.; Yi, G.; Tran, C.N.N. A system dynamics-based environmental benefit assessment model of construction waste reduction management at the design and construction stages. J. Clean. Prod. 2018, 176, 676-692. [CrossRef] 
24. Ivancevich, J.M.; McMahon, J.T. The effects of goal setting, external feedback, and self-generated feedback on outcome variables: A field experiment. Acad. Manag. J. 1982, 25, 359-372.

25. Ogunlana, S.O.; Li, H.; Sukhera, F.A. System Dynamics Approach to Exploring Performance Enhancement in a Construction Organization. J. Constr. Eng. Manag. 2003, 129, 528-536. [CrossRef]

26. Nasirzadeh, F.; Nojedehi, P. Dynamic modeling of labor productivity in construction projects. Int. J. Proj. Manag. 2013, 31, 903-911. [CrossRef]

27. Ford, D.; Sterman, J. Dynamic modeling of product development processes. Syst. Dyn. Rev. 1998, 14, 31-68. [CrossRef]

28. Lee, S.; Peña-Mora, F.; Park, M. Quality and Change Management Model for Large Scale Concurrent Design and Construction Projects. J. Constr. Eng. Manag. 2005, 131, 890-902. [CrossRef]

29. Lee, S.H.; Peña-Mora, F. Understanding and managing iterative error and change cycles in construction. Syst. Dyn. Rev. 2007, 23, 35-60. [CrossRef]

30. Motawa, I.A.; Anumba, C.J.; Lee, S.; Peña-Mora, F. An integrated system for change management in construction. Autom. Constr. 2007, 16, 368-377. [CrossRef]

31. Han, S.; Love, P.; Peña-Mora, F. A system dynamics model for assessing the impacts of design errors in construction projects. Math. Comput. Model. 2013, 57, 2044-2053. [CrossRef]

32. Yuan, H.P.; Shen, L.Y.; Hao, J.J.L.; Lu, W.S. A model for cost-benefit analysis of construction and demolition waste management throughout the waste chain. Resour. Conserv. Recycl. 2011, 55, 604-612. [CrossRef]

33. Golroudbary, S.R.; Zahraee, S.M. System dynamics model for optimizing the recycling and collection of waste material in a closed-loop supply chain. Simul. Model. Pract. Theory 2015, 53, 88-102. [CrossRef]

34. Chen, C. A Proactive Approach for Change Management and Control on Construction Projects; University of California: Berkeley, CA, USA, 2015.

35. Thomas, S.J. Using Web and Paper Questionnaires for Data-Based Decision Making: From Design to Interpretation of the Results; Corwin Press: Thousand Oaks, CA, USA, 2004; ISBN 1506318487.

36. Botter, C.H. Project management: A systems approach to planning, scheduling and controlling. Eur. J. Oper. Res. 1982, 10, 211. [CrossRef]

37. Panova, Y.; Hilletofth, P. Managing supply chain risks and delays in construction project. Ind. Manag. Data Syst. 2018, 118, 1413-1431. [CrossRef]

38. Nasirzadeh, F.; Carmichael, D.G.; Jarban, M.J.; Rostamnezhad, M. Hybrid fuzzy-system dynamics approach for quantification of the impacts of construction claims. Eng. Constr. Arch. Manag. 2019, 1-16. [CrossRef]

39. Hussain, S.; Fangwei, Z.; Siddiqi, A.; Ali, Z.; Shabbir, M. Structural equation model for evaluating factors affecting quality of social infrastructure projects. Sustainability 2018, 10, 1415. [CrossRef]

40. Xu, X.; Wang, J.; Li, C.Z.; Huang, W.; Xia, N. Schedule risk analysis of infrastructure projects: A hybrid dynamic approach. Autom. Constr. 2018, 95, 20-34. [CrossRef] 